Access this article online

Website:

onbt.scholasticahq.com

DOI:

10.18639/ONBT.2016.03.1255

\section{Sarcomatoid carcinoma of kidney, presenting with leucocytosis as paraneoplastic syndrome: A case report and short review}

\author{
Joydeep Ghosh ${ }^{1}$, Rahul Surve ${ }^{2}$, Ashish Pokharkar ${ }^{3}$, Suvarna Patil2, \\ Nandini Sharma ${ }^{4}$, S D Banavali ${ }^{5}$
}

${ }^{1}$ Department of Medical Oncology, Tata Memorial Hospital, Mumbai, ${ }^{2}$ Consultant Physician, BKL Walawalkar Hospital, Derwan, Ratnagiri,

${ }^{3}$ Department of

Surgical Oncology,

Tata Memorial Hospital,

Mumbai, ${ }^{4}$ Clinical

Researcher, BKL

Walawalkar Hospital,

Derwan, Ratnagiri,

${ }^{5}$ Department of

Medical Oncology, Tata

Memorial Hospital,

Parel, Mumbai

Address for correspondence:

Joydeep Ghosh, Department of Medical Oncology, Tata Memorial Hospital, Mumbai. dr.joydeep.ghosh@gmail.com Phone No.: +91-22-24177287

Submission: 13-07-16 Accepted: 26-10-16

\begin{abstract}
:
Renal cell carcinoma is the ninth most common malignancy. The commonest histopathological type is clear cell carcinoma. The occurrence of sarcomatoid carcinoma is very rare and confers a very poor prognosis. Only $10-20 \%$ patients present with paraneoplastic syndromes. Out of the common paraneoplastic syndromes, leucocytosis is one of the least reported. Here, we present a case of sarcomatoid carcinoma of kidney who presented with low-grade fever and leucocytosis, followed by a short review of literature. This is one of the rare situations where a rare histologic variant presents with a rare finding.

Key words:

Sarcomatoid carcinoma, kidney
\end{abstract}

\section{Introduction}

Sarcomatoid carcinoma of the kidney is a rare Shistology that is encountered after radical nephrectomies. As of today, the prognosis has been poor with standard therapeutic principles that are being extrapolated from the management of clear cell renal cancer. Due to the rarity, the prognostication, need for adjuvant therapies, need for adding systemic chemotherapy for metastatic disease, contribution of cytoreductive nephrectomy and various other aspects have not been addressed properly. We only have data from a few case reports on how to manage this patient subset. Here, we present a similar case and review the data till now on management.

\section{Case Report}

A 58-year-old male, who was hypertensive, on medications and well controlled, presented to us with the complaints of low-grade fever and weakness for 2 months. There was no history of any weight loss or any other localizing symptoms. On routine investigation at local place, a complete blood count suggested leucocytosis. Suspected of a haematological malignancy, he was referred to our hospital for further management.

At presentation, he was alert and conscious. His vitals were pulse: $82 / \mathrm{min}$ regular, blood pressure: $150 / 90$, respiratory rate: $22 / \mathrm{min}$ and temperature: 98 degrees F. He had pallor, with no evidence of jaundice or oedema. No nodes were palpable in the neck or other sites. Chest examination was normal. Abdomen examination did not reveal any organomegaly. Rest of the systemic examination was within normal limits.

On investigation, haemoglobin was $5.4 \mathrm{gm} / \mathrm{dl}$, red blood cell indices normocytic, normochromic with a total leucocyte count of $66,000 / \mathrm{cu} \mathrm{mm}$. Differential count was N65 L25 E3 B3 M4. Creatinine was $1.5 \mathrm{mg} / \mathrm{dl}$, urea $40 \mathrm{mg} / \mathrm{dl}$ and liver functions were within normal limits. Chest X-ray was done to rule out any infective foci, and it was normal. All his laboratory parameters are summarised in Table 1.

In view of raised counts and low-grade fever, he was started on oral antibiotics with a presumption of an infective cause. However, after 5 days of oral antibiotics, repeat complete blood count (CBC) was done, which showed no change in the total leukocyte count. CRP was done this time, which was normal. To differentiate it from myeloproliferative disorder, we sent the LAP score, which was $1.5 \times$ times the upper limit of normal for the reference range of the lab. So, we started investigating for any underlying cause for leucocytosis. A CECT of abdomen/pelvis was done, which revealed a renal mass in the 
Table 1: Baseline laboratory parameters

\begin{tabular}{ll}
\hline Haemoglobin & $5.4 \mathrm{gm} / \mathrm{dl}$ \\
Total leukocyte count & $66,000 / \mathrm{cu} \mathrm{mm}$ \\
Differential count & N65 L25 E3 B3 M4 \\
Platelet count & 5.6 lakhs/cu mm \\
ESR & $56 \mathrm{~mm} 1 \mathrm{st} \mathrm{hour}$ \\
Serum Na & $135 \mathrm{meq} / \mathrm{L}$ \\
Serum K+ & $3.9 \mathrm{meq} / \mathrm{L}$ \\
lonised calcium & $9.4 \mathrm{mg} / \mathrm{dl}$ \\
Bilirubin & $0.6 \mathrm{mg} / \mathrm{dl}$ \\
SGOT & $46 \mathrm{U} / \mathrm{L}$ \\
SGPT & $66 \mathrm{U} / \mathrm{L}$ \\
Serum alkaline phosphate & $136 \mathrm{KA} / \mathrm{L}$ \\
LDH & $350 \mathrm{U} / \mathrm{L}(1.5 \times$ upper limit of normal \\
LAP score & 251 (raised) \\
Creatinine & $1.5 \mathrm{gm} / \mathrm{dl}$ \\
Urea & $40 \mathrm{mg} / \mathrm{dl}$ \\
\hline
\end{tabular}

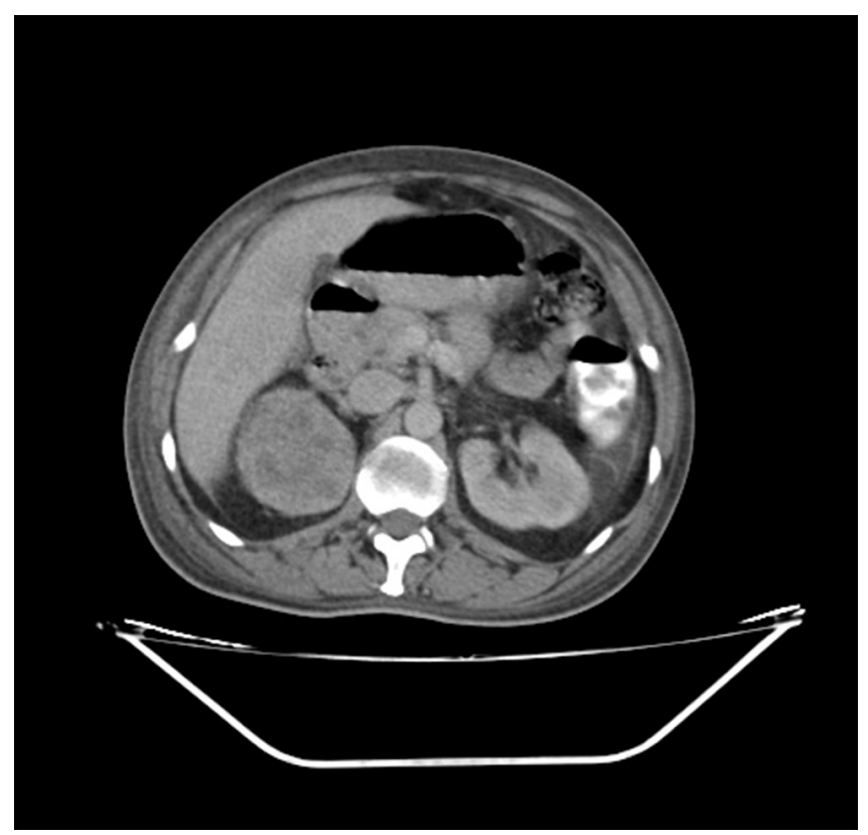

Figure 1: CT scan of the abdomen showing the tumor involving the right kidney, showing heterogenous architecture, with areas of necrosis inside

upper pole of the right kidney, $7 \mathrm{~cm}$ in largest diameter with heterogeneous enhancement. The radiological picture was suggestive of renal cell carcinoma. Metastatic workup with the CECT of thorax revealed multiple lung metastases. He did not have any bone pain and serum ALP was normal, so bone scan was not done. Heng's score was calculated, which came out to be intermediate risk. With proper explanation of the disease prognosis and outcomes, we did right radical nephrectomy after proper optimisation of haemoglobin, which is the standard procedure for metastatic renal cell carcinoma. Final histopathology revealed sarcomatoid carcinoma with some areas of clear cell morphology renal cell carcinoma, Fuhrman grade III [Figure 1]. Margins were clear; 8 out of 12 retroperitoneal nodes dissected were positive for metastasis.

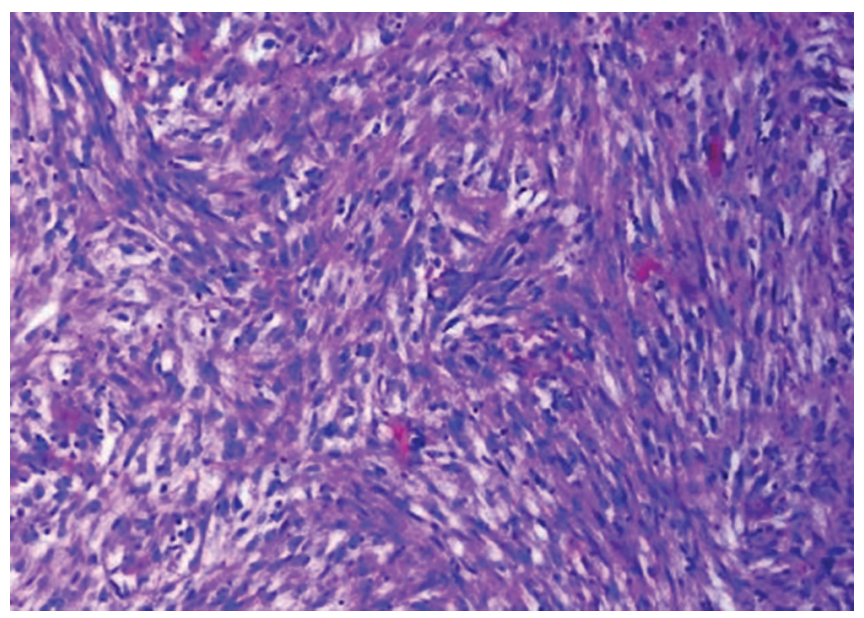

Figure 2: Histopathology of the tumor that shows sheets of cells with spindle type morphology, that is characteristic of sarcomatoid carcinoma of the lung. There is paucity of the typical clear cell morphology, typically seen in conventional clear cell carcinoma of the kidney

He was planned for systemic therapy with sunitinib. However, the patient as well as the relatives did not want any further treatment and wanted to go for alternative therapy. So, he was discharged from the hospital with proper counselling about the prognosis. Unfortunately, the patient came back to us after 15 days with acute respiratory failure. He was taken to ICU and started on mechanical ventilation with vasopressor support. But he could not be salvaged and died of severe metabolic acidosis.

\section{Review of Literature}

Renal cell carcinoma, based on the data from developed countries, is considered to be the malignancy of the sixth and seventh decade of life. As per the Globocan data, it is the ninth most common cancer in the world. In India, many patients present at a younger age and in advanced stage of the disease. Incidence globally is around 2.1 lakhs, out of which, mortality is around $90,000 .^{[1]}$

It is estimated that $10-40 \%$ of patients develop paraneoplastic syndromes. ${ }^{[2]}$ The most common syndromes are hypocalcaemia, hypertension, polycythaemia, hepatic dysfunction and constitutional symptoms. ${ }^{[3]}$ In some series, the presence of paraneoplastic syndromes has conferred poor prognosis. ${ }^{[4]}$ The presence of leucocytosis at presentation is very rare. Some of them have been described in animals. Data in human beings are still a few. One case report has shown increased levels of G-CSF as a cause of leukocytosis. ${ }^{[5]}$ In another case report from the Netherlands, a 79-year-old female with RCC presented with low-grade fever, weight loss and overt granulocytosis and thrombocytosis. They demonstrated increased levels of IL-1alpha, IL-1beta, IL- 8 and ICAM-1 in the tumour with systemic elevated levels of IL- 6 and IL- 8 with secondary increased serum G-CSF and TPO levels. ${ }^{[6]}$ Another pair case report from Huang et al. showed the presence of leukemoid reaction after nephrectomy was done. ${ }^{[7]}$ One case of papillary carcinoma of kidney also presented with baseline leukocytosis. ${ }^{[8]}$ 
Our case is unique about the fact that a rare variant of renal cell carcinoma has presented with a rare paraneoplastic feature. This case underlines the importance of searching for an underlying malignancy, when we diagnose a case of leucocytosis, without any evidence of hematologic malignancy. The outcome of sarcomatoid carcinoma of kidney is very poor. The incidence of metastatic disease is extremely high at presentation, with $45-84 \%$ having evidence of systemic disease. ${ }^{[9-11]}$ One- and two-year overall survival rates were 48 and $37 \%$, respectively, in one study, in the interleukin era. ${ }^{[11]}$ In one study by Kwak et al., the survival of sarcomatoid variant was found to be 3.2 months compared to nonsarcomatoid variant. ${ }^{[12]}$

In conclusion, renal cell carcinoma can rarely present with nonspecific weakness and leucocytosis resembling myeloproliferative disorder. The recognition of the underlying cause of leucocytosis should be of utmost importance, because of the need of early institution of best possible therapy in this poor prognostic subset of patients.

Patient consent statement

Informed consent was obtained from the patient prior to the study.

\section{References}

1. http://globocan.iarc.fr/Pages/fact_sheets_population.aspx, last accessed June 2016.

2. Palapattu GS, Kristo B, Rajfer J. Paraneoplastic syndromes in urologic malignancy: The many faces of renal cell carcinoma. Rev Urol 2002;4(4):163-70.

3. Laski ME, Vugrin D. Paraneoplastic syndromes in hypernephroma. Semin Nephrol 1987 Jun;7(2):123-30.

4. Kim HL, Belldegrun AS, Freitas DG, Bui MH, Han KR, Dorey FJ, et al. Paraneoplastic signs and symptoms of renal cell carcinoma: Implications for prognosis. J Urol 2003 Nov; 170(5):1742-6.
5. Wang YC, Yang S, Tzen CY, Lin CC, Lin J. Renal cell carcinoma producing granulocyte colony-stimulating factor. J Formos Med Assoc 2006 May;105(5):414-7.

6. van Rossum AP, Vlasveld LT, Vlasveld IN, Jansen PM, Dik WA, Hooijkaas $\mathrm{H}$, et al. Granulocytosis and thrombocytosis in renal cell carcinoma: A pro-inflammatory cytokine response originating in the tumour. Neth J Med 2009 May;67(5):191-4.

7. Huang W, Wang F, Li Y, Duan F, Yu Z. Leukemoid reaction in sarcomatoid renal cell carcinoma: A two-case report. World J Surg Oncol 2014 Apr 19;12:100. doi: 10.1186/1477-7819-12-100.

8. Mandal SK, Ganguly J, Sil K, Mondal SS, Sardar D, Sarkar P. Renal cell carcinoma with paraneoplastic leucocytosis. J Can Res Ther 2015;11:660.

9. Cheville JC, Lohse CM, Zincke H, Weaver AL, Leibovich BC, Frank I, et al. Sarcomatoid renal cell carcinoma: An examination of underlying histologic subtype and an analysis of associations with patient outcome. Am J Surg Pathol 2004 Apr;28(4):435-41.

10. Mian BM, Bhadkamkar N, Slaton JW, Pisters PW, Daliani D, Swanson DA, et al. Prognostic factors and survival of patients with sarcomatoid renal cell carcinoma. J Urol 2002 Jan;167(1):65-70.

11. Cangiano T, Liao J, Naitoh J, Dorey F, Figlin R, Belldegrun A. Sarcomatoid renal cell carcinoma: biologic behavior, prognosis, and response to combined surgical resection and immunotherapy. J Clin Oncol 1999 Feb;17(2):523-8.

12. Kwak C, Park YH, Jeong CW, Jeong H, Lee SE, Moon KC, et al. Sarcomatoid differentiation as a prognostic factor for immunotherapy in metastatic renal cell carcinoma. J Surg Oncol 2007 Mar 15;95(4):317-23.

This is an open access article distributed under the terms of the Creative Commons Attribution-NonCommercial-ShareAlike 3.0 License, which allows others to remix, tweak, and build upon the work non-commercially, as long as the author is credited and the new creations are licensed under the identical terms.

How to cite this article: Ghosh J, Surve R, Pokharkar A, Patil S, Sharma N, Banavali SD. Sarcomatoid carcinoma of kidney, presenting with leucocytosis as paraneoplastic syndrome: A case report and short review. Oncobiol Targets 2016;3:8.

Source(s) of Support: None. Conflicting Interest: None. 